\title{
A Iniciativa Popular e sua Relação com as Iniciativas Privativas do Presidente da República.
}

\author{
UBERGUE RIBEIRO JUNIOR \\ Advogado da União, Assessor da Subchefia para Assuntos Jurídicos da Casa Civil \\ da Presidência da República
}

\begin{abstract}
Sumário - 1. Introdução - 2. A iniciativa popular e sua interpretação lógicorestritiva. - 3. A iniciativa popular e sua real dimensão. Uma nova perspectiva. -3.10 art.61 da Constituição e o sistema de freios e contrapesos. -3.2 Poder discricionário, legitimidade e soberania popular. - 4. A iniciativa popular e sua interpretação sistemática. -5 . A iniciativa popular sob a ótica da nova hermenêutica constitucional. -5.10 método integrativo ou espiritual-científico, a tópica constitucional e a concretização estruturante de Friedrich Müller. -5.2 Um paralelo entre a iniciativa popular e a teoria da sociedade aberta dos intérpretes da Constituição de Peter Häberle - 6. Aplicabilidade da disjunção de normas e do catálogo tópico dos princípios de interpretação constitucional à iniciativa popular. -7 . Conclusão. -8 . Bibliografia
\end{abstract}

\section{Introdução}

A complexidade das atuais relações intersubjetivas vem continuamente dando à doutrina um caráter de imprescindibilidade cada vez maior. No bojo de sua atividade orientadora, é dela o papel fundamental de construir argumentos levando-se em conta a sua principal arma: $a$ interpretação.

Esta arma, ou melhor, este molde onde se põe a matéria-prima para a construção de um pensamento, inspira não só as especulações da própria doutrina, como também, influencia sobremaneira os enunciados jurisprudenciais e as decisões políticas, estas últimas, como condição indissociável para a produção legislativa.

Neste conspecto, não seria ousadia afirmar que a hermenêutica é a pró- pria essência da atividade jurídica, já que é nela onde mora o espírito proletário do intérprete, e é nela onde ele encontra sua rotina e sua provação.

Não obstante os inúmeros revezes históricos e doutrinários, o trabalho de interpretação parece estar readquirindo forças com a falência do modelo purificado e auto-suficiente das super-construções dogmáticas. Aliás, uma das tantas coisas que a inexauribilidade da vida já fez questão de ensinar é que nada é tão auto-suficiente assim. Estamos todos, a todo o momento, precisando de algo ou de alguém. Por mais que os homens dediquem suas melhores horas para a construção de um super-sistema jurídico - puro, dogmatizado e calculista - nenhum "super-sistema" será capaz de imaginar para si a condição de auto-suficiência. 
Se os homens tanto precisam de um sistema moderno, enxuto, progressista, este mesmo sistema tanto irá precisar do engenho humano. Decerto, independentemente do tempo e do lugar, sempre vão existir as lacunas, os hiatos, as divergências, e para dirimir todas elas, sempre vai existir a interpretação. ${ }^{1}$

Com efeito, é justamente dentro de todo esse contexto que o presente estudo vem examinar a iniciativa popular (art.61, $\$ 2^{\circ}$ ) e sua relação com as iniciativas privativas do Presidente da República (art.61, $\$ 1^{\circ}$ ). De uma maneira ainda mais pragmática, o objetivo é construir uma interpretação jurídica que permita a um projeto de lei, oriundo de iniciativa popular, e tão-somente neste caso, desvencilharse das reservas impostas pelo $₫ 1^{\circ}$ do art.61, reconhecendo-se, ao final, a sua real e verdadeira essência como instrumento da cidadania e da soberania popular.

Dentro desta perspectiva, fundamental é a lição de Mário Moacyr
Porto: "A lei não esgota o Direito, como a partitura não exaure a música. Interpretar é recriar, pois as notas musicais, como os textos de lei, são processos técnicos de expressão, e não meios inextensíveis de exprimir. Há virtuoses do piano que são verdadeiros datilógrafos do teclado. Infiéis à música, por excessiva fidelidade às notas, são instrumentalistas para serem escutados, e não intérpretes para serem entendidos. $O$ mesmo acontece com a exegese da lei jurídica.Aplicá-la é exprimi-la, não como uma disciplina limitada em si mesma, mas como uma direção que se flexiona às sugestões da vida".

Na verdade, o conceito de plasticidade sempre esteve presente na construção dos objetos culturais, e apesar da variabilidade histórica dessa noção de plasticidade, nenhuma empreitada humana jamais a dispensou.

A Constituição, como objeto cultural que é, também se vale de uma atmosfera plástica para exprimir seus conceitos mais significativos. Não é

1 "Por mais hábeis que sejam os elaboradores de um código, logo depois de promulgado surgem dificuldades e dúvidas sobre a aplicação de dispositivos bem redigidos. Uma centena de homens cultos e experimentados seria incapaz de abranger em sua visão lúcida a infinita variedade dos conflitos de interesses entre os homens. Não perdura o acordo estabelecido, entre o texto expresso e as realidades objetivas. Fixou-se o Direito Positivo; porém a vida continua, evolve, desdobra-se em atividades diversas, manifesta-se sob aspectos múltiplos: morais, sociais, econômicos. Transformam-se as situações, interesses e negócios que teve o Código em mira regular. Surgem fenômenos imprevistos, espalham-se novas idéias, a técnica revela coisas cuja existência ninguém poderia presumir quando o texto foi elaborado. Nem por isso se deve censurar o legislador, nem reformar a sua obra.A letra permanece: apenas o sentido se adapta às mudanças que a evolução opera na vida social". Maximiliano, Carlos. Hermenêutica e Aplicação do Direito. Rio de Janeiro: Forense, 1993, p.12.

2 Porto, Mario Moacyr. Estética do Direito. Revista do Curso de Direito da Universidade Federal do Rio Grande do Norte.Vol.01, n. ${ }^{\circ} 01$. Natal:CEJ/RN, EDurRN, 1996. 
à toa que os fundamentos, objetivos, princípios e valores da Constituição absorvem todas as suas primeiras manifestações. Por tudo isto, interpretar 0 art.61 e seus $\$ \delta 1^{\circ}$ e $2^{\circ}$, sem uma correspondência madura com todos esses aspectos iniciais, é a mesma coisa que ouvir uma nota isolada do seu conjunto harmônico, ou o mesmo que ler uma estrofe apartada de sua poesia. Se essas extrações são fatais para as artes, também o são para as Ciências Humanas, e, por conseguinte, para o Direito. Seguindo as linhas de Mário Moacyr Porto, a verdade da partitura não se alcança com a sua mera execução, mas sim, com a sua interpretação.

O propósito deste trabalho, portanto, não é exaurir a fonte da iniciativa popular, mas sim, buscar para ela, e em especial para o art.61, $\$ \mathbb{1}^{\circ}$ e $2^{\circ}$, uma interpretação menos estática, menos cômoda, mais vanguardista e (por que não dizer?), mais de acordo com o espírito da própria Constituição.

\section{A iniciativa popular e sua} interpretação lógico-restritiva.

A iniciativa popular, em linhas gerais, é o instrumento segundo o qual a Constituição viabiliza, formalmente, a possibilidade de os cidadãos serem os responsáveis diretos pela propositura de um projeto de lei. Criada pelo constituinte originário, ela é um dos expoentes da soberania popular (art.14, III, da Constituição), onde os cidadãos, reunidos e organizados nos termos do art.61, $\$ 2^{\circ}$, da Constituição, podem apresentar à Câmara dos Deputados um projeto de lei oriundo da mais legítima vontade social.

Muito embora sua previsão formal esteja conjugada, como dito, em dois dispositivos - art.14, III e art.61, $₫ 2^{\circ}$ - sua verdadeira compreensão envolve um contingente doutrinário muito mais amplo e complexo, exigindo do hermeneuta uma interpretação que não fique apenas restrita a um ou outro preceito normativo, e em especial, ao art.61 da Constituição.

A propósito, observando o art.61 e seus parágrafos, a primeira impressão que se tem destes dispositivos é que não há ali qualquer espaço que enseje uma interpretação não-literal. De fato, uma primeira e apressada leitura remete o intérprete a um abrigo técnico e formal, que leva em consideração tão-somente aspectos semânticos e gramaticais do texto, sob a égide de um "pressuposto lógico de inclusões e exclusões".

Tal pressuposto lógico está fulcrado na seguinte situação: existe um artigo, in casu, o art. 61 e seus $\$ \$ 1^{\circ} \mathrm{e} 2$ $\circ$. O seu caput traz uma situação geral, o primeiro parágrafo complementa uma regra do caput - impondo uma restrição, qual seja, a indicação de matérias reservadas à iniciativa do Presidente da República - e o segundo parágrafo molda os alicerces do exercício da iniciativa popular. Com ser assim, o resultado não poderia ser outro: 
Art. 61. A iniciativa das leis complementares e ordinárias cabe a qualquer membro ou Comissão da Câmara dos Deputados, do Senado Federal ou do Congresso Nacional, ao Presidente da República, ao Supremo Tribunal Federal, aos Tribunais Superiores, ao Procurador-Geral da República e aos cidadãos, na forma e nos casos previstos nesta Constituição.

$\int 1^{0}$ - São de iniciativa privativa do Presidente da República as leis que:

I - fixem ou modifiquem os efetivos das Forças Armadas;

II - disponham sobre:

a) criação de cargos, funções ou empregos públicos na administração direta e autárquica ou aumento de sua remuneração;

b) organização administrativa e judiciária, matéria tributária e orçamentária, serviços públicos e pessoal da administração dos Territórios;

c) servidores públicos da União e Territórios, seu regime jurídico, provimento de cargos, estabilidade e aposentadoria;

d) organização do Ministério Público e da Defensoria Pública da União, bem como normas gerais para a organização do Ministério Público e da Defensoria Pública dos Estados, do Distrito Federal e dos Territórios;

e) criação e extinção de Ministérios e órgãos da administração pública, observado o disposto no art. 84, VI;

f) militares das Forças Armadas, seu regime jurídico, provimento de cargos, promoções, estabilidade, remuneração, reforma e transferência para a reserva. $\int 2^{\circ}-\mathrm{A}$ iniciativa popular pode ser exercida pela apresentação à Câmara dos Deputados de projeto de lei subscrito por, no mínimo, um por cento do eleitorado nacional, distribuído pelo menos por cinco Estados, com não menos de três décimos por cento dos eleitores de cada um deles.

Como se vê, o exame inicial deixa claro a existência de um sistema de inclusões subjetivas (determinando quem são os legitimados para dar início ao processo legislativo), e por outro lado, um sistema de exclusões objetivas (determinando as matérias que estão fora da iniciativa geral descrita no caput).

Assim, segundo essa linha de raciocínio, o caput traz uma regra geral, o seu $₫ 1^{\circ}$ excetua algumas matérias àquela regra geral, e o resultado, dentro desta ótica, fica de fácil percepção: as reservas do $\mathbb{N} 1^{\circ}$ (exclusões objetivas) se estendem a todos os legitimados do caput (inclusões subjetivas), razão pela qual, um projeto de lei, oriundo da iniciativa popular, não poderia versar sobre as matérias reservadas à iniciativa privativa do Presidente da República.

Esta com toda certeza é a conclusão que se chega dentro da ótica restrita do art.61 da Constituição. Sobre o tema, Mônica de Melo manifesta seu pensamento: "Quanto à questão dos limites de matéria, queremos trazer a experiência da Constituição do Estado de São Paulo, que procura estabelecer um limite material quando 
determina que não serão suscetíveis de iniciativa popular matérias de iniciativa exclusiva [...].Tal limitação, a nosso ver, é correta, uma vez que a soberania popular deve ser exercida dentro dos limites estabelecidos pela própria Constituição". ${ }^{3}$

Sob a mesma égide, Manoel Gonçalves Ferreira Filho também se posiciona: "A iniciativa geral - regra de que a iniciativa reservada é a exceção - compete concorrentemente ao Presidente da República, a qualquer deputado ou senador e a qualquer das casas do Congresso. E, acréscimo da Constituição em vigor, ao povo. Observe-se que, em face das reservas de iniciativa adiante examinadas, rigorosamente falando, no Direito brasileiro ninguém possui realmente iniciativa geral. [...] Seguindo uma tendência difundida, a Lei Magna de 1988 consagra a iniciativa popular (art. 61). É esta uma iniciativa geral no sentido acima, já que não está adstrita a matérias determinadas. Pela lógica, todavia, não alcança as matérias reservadas."

Repise-se esta última consideração: "[...] Pela lógica, todavia, não alcança as matérias reservadas". Essa passagem é importante, porque ratifica, em sede doutrinária, a interpretação lógico-restritiva do art. 61 , segundo a qual um projeto de lei de origem popular não poderia dispor das matérias constantes do $₫ 1^{\circ}$ do art. 61 .

No entanto, o que é preciso investigar é se essa interpretação restritiva, baseada numa lógica manifestamente fechada, é a melhor alternativa para a verdadeira compreensão da iniciativa popular e sua relação com a iniciativa privativa do Presidente da República.

Como se sabe, há situações no universo jurídico que a simples aplicação do texto da lei convence e satisfaz. Por exemplo, se a Constituição diz que uma emenda constitucional para ser aprovada precisa de um quorum de $3 / 5$, não há razão para defender um quorum de 2/3. De igual teor e forma, se a iniciativa de proposta de emenda é de $1 / 3$ dos membros da Câmara ou do Senado, não adianta um só Deputado ou Senador tentar dar início a uma reforma constitucional, que sua empreitada estará fadada ao insucesso.

Nesses casos, e em muitos outros, a interpretação literal está isenta de críticas.Apesar de ser a mais pobre intelectualmente falando, ela não é menos importante. O problema é que, mesmo

3 Melo, Mônica de. Plebiscito, referendo e iniciativa popular. Mecanismos constitucionais de participação popular. Porto Alegre: Sergio Antônio Fabris Editor, 2001, p.194.

4 Ferreira Funo, Manoel Gonçalves. Do processo legislativo. $4^{a}$ edição. São Paulo: Saraiva, 2001, p.207.Ainda que de maneira não explícita, parecem seguir a mesma tendência:André Ramos Tavares, (Curso de Direito Constitucional, $2^{a}$ edição. São Paulo: Saraiva, 2003, p.910911) e José Afonso da Silva (Curso de Direito Constitucional Positivo. $19^{a}$ edição. São Paulo: Malheiros, 2000 p.527). 
não sendo a menos importante, ela é a que mais traz estratificação ao Direito, impedindo-o de acompanhar o ritmo das mutações sociais.

Dessa forma,é dever do intérprete, sempre que estiver analisando uma norma - principalmente aquelas normas que dão ensejo a uma interpretação literal - observar, antes de qualquer outra coisa, se esta dá a ele um espaço de interpretação que the possibilite adotar uma outra ótica, que não apenas a literal.

Cotejando todos esses dados abstratos com a matéria pragmática sub examine, por mais que exista no art.61 da Constituição uma aparência de taxatividade e clarividência, no sentido de que um projeto de lei, fruto de iniciativa popular, não poderia versar sobre as matérias reservadas ao Presidente da República, esta cer teza, como dito, é apenas aparente. Não é à-toa, aliás, que o brocardo latino in claris cessat interpretatio, bastante vigoroso em outros tempos, perdeu completamente a sua razão de ser $^{5}$, hoje prevalecendo a idéia de que toda norma deve ser interpretada. ${ }^{6}$

A esse respeito, imprescindível também é a lição de Jorge Miranda: "Há sempre que interpretar a Constituição como há sempre que interpretar a lei. Só através dessa tarefa se passa da leitura política,ideológica ou simplesmente empírica para a leitura jurídica do texto constitucional, seja ele qual for. Só através dela, a partir da letra, mas sem se parar na letra, se encontra a norma ou o sentido da norma"?

A par dessa assertiva, não é porque uma norma é aparentemente clara que o intérprete irá dispensar uma investigação jurídica mais aprofundada ou até mesmo outras interpretações, que não seja apenas a literal.

Isto posto, considerando: a) que essa primeira leitura do art.61 e seus dois parágrafos é demasiadamente restrita, levando-se em conta apenas a sua lógica fechada e olvidando os demais aspectos, princípios e fun-

5 Neste sentido, diz Carlos Maximiliano: "Disposições claras não comportam interpretação - Lei Clara não carece de interpretação - Em sentido claro o texto, não se admite pesquisa da vontade - famoso dogma axiomático, dominador absoluto dos pretórios há meio século; afirmativa sem nenhum valor científico, ante as idéias triunfantes na atualidade". Mais adiante, diz ainda o citado mestre:"Os domínios da hermenêutica se não estendem só aos textos defeituosos; jamais se limitam ao invólucro verbal: o objetivo daquela disciplina é descobrir o conteúdo da norma, o sentido e o alcance das expressões do Direito. Obscuras ou claras, deficientes ou perfeitas, ambíguas ou isentas de controvérsia, todas as frases jurídicas aparecem aos modernos como suscetíveis de interpretação". Carlos Maximiliano, ob.cit. p. 33 e 35 .

6 Tanto é assim que Peter Häberle chega a afirmar que "não há norma jurídica senão norma jurídica interpretada".

7 Miranda, Jorge. Manual de Direito Constitucional. Introdução a Teoria da Constituição,Tomo II. $2^{a}$ edição. Coimbra Editora Ltda. p.224. 
damentos da Constituição; b) que a clarividência de alguns pontos destes dispositivos é apenas aparente, não ensejando nenhuma certeza jurídica definitiva, e c) que há sim um espaço de interpretação que dá ao intérprete condições de fazer uma interpretação não apenas literal, mas com base em uma série de outras diretrizes doutrinárias, passa-se, doravante, a construir uma nova perspectiva em relação ao "poder" da iniciativa popular.

\section{A iniciativa popular e sua real dimensão. Uma nova perspectiva.}

Conforme mencionado em linhas anteriores, $o$ intérprete precisa fazer uma leitura apurada de cada norma jurídica, quer seja ela clara ou não. Trazendo essa orientação para o caso concreto e procurando identificar outros elementos que porventura não estejam contidos dentro da ótica fechada do art. 61, chega-se à conclusão de que ali, quase imperceptível no caput, existe uma previsão normativa que, associada aos demais princípios, valores e fundamentos constitucionais, põe por terra a interpretação de que os projetos de lei, oriundos de iniciativa popular, são submetidos aos mesmos ditames dos demais projetos (iniciativa parlamentar, por exemplo), inclusive, em relação ao $\$ 1^{\circ}$ do art. 61 .

Art. 61. A iniciativa das leis complementares e ordinárias cabe a qualquer membro ou Comissão da Câmara dos Deputados, do Senado Federal ou do Congresso Nacional, ao Presidente da República, ao Supremo Tribunal Federal, aos Tribunais Superiores, ao Procurador-Geral da República e aos cidadãos, na forma e nos casos previstos nesta Constituição.

(...)

$\S 2^{\circ}-\mathrm{A}$ iniciativa popular pode ser exercida pela apresentação à Câmara dos Deputados de projeto de lei subscrito por, no mínimo, um por cento do eleitorado nacional, distribuído pelo menos por cinco Estados, com não menos de três décimos por cento dos eleitores de cada um deles.

Tal previsão é justamente a faculdade que a lei confere aos cidadãos de poder movimentar o processo legislativo através de um instituto de soberania popular ${ }^{8}$, a saber, a iniciativa popular, corolário que é do princípio democrático. Quando foi mencionado que esta previsão normativa estava quase imperceptível no caput, o objetivo era demonstrar como o conjunto de autoridades ofuscava a participação dos cidadãos, chegando ao ponto de minorar o status constitucional diferenciado destes

8 "[...] o princípio da soberania popular compendia as regras básicas de governo e de organização estrutural do ordenamento jurídico, sendo, ao mesmo passo, fonte de todo o poder que legitima a autoridade e se exerce nos limites consensuais do contrato social. Encarna o princípio do governo democrático e soberano, cujo sujeito e destinatário na concretude do sistema é o cidadão". Bonavides, Paulo. Teoria constitucional da democracia participativa. $2^{\text {a }}$ ed. São Paulo: Malheiros, 2003, p.11. 
últimos, ante uma regra distorcida de igualdade.

Explica-se. Numa cultura voltada (e desviada) para a superdimensão da autoridade constituída, os cidadãos, até mesmo quando recebem a dádiva da co-legitimação para a iniciativa de um projeto de lei,ficam prejudicados pela não observância do postulado mais elementar do princípio da igualdade: "a regra da igualdade não consiste senão em aquinhoar desigualmente aos desiguais, na medida em que se desigualam. Nesta desigualdade social, proporcionada à desigualdade natural, é que se acha a verdadeira lei da igualdade".

Assim, os cidadãos, que sempre buscaram um pé de igualdade com as demais autoridades constituídas, só conseguem atingir tal desiderato, quando este padrão de igualdade não interessa aos próprios cidadãos. E não interessa, porque a simples previsão "cidadãos" descrita no caput do art. 61 - previsão esta, inclusive, que faz nascer o instituto da iniciativa popular no $\mathbb{I} 2^{\circ}$ do mesmo artigo - dá um status constitucional a eles, totalmente diverso daquele atribuído às autoridades oficiais.

A situação dos cidadãos, como se vê, não pode ser encarada da mesma maneira dos demais legitimados a propor um projeto de lei. Os cidadãos não são autoridades constituídas, pertencentes a um poder, e por tal motivo, precisam de um tratamento diferenciado ${ }^{10}$, não podendo, destarte, fazer parte de uma regra geral, que é,e sempre foi, destinada aos poderes da república e suas autoridades.

Fundamental é registrar a importância dessas asseverações. Por mais que a interpretação lógico-restritiva não contemple a dimensão total do que significa a iniciativa popular, a singela colocação dos cidadãos no caput do art.61 faz nascer, de uma lógica outrora fechada, uma outra perspectiva jurídica: a de que os cidadãos não se submetem às mesmas regras restritivas aplicáveis às demais autoridades.

9 Cf. Rui Barbosa em sua Oração aos Moços.

10 Para demonstrar até onde vai a lei para legitimar esse tratamento diferenciado, vide o que diz a Lei n. ${ }^{\circ} 9.709 / 98$ :

Art. 13.A iniciativa popular consiste na apresentação de projeto de lei à Câmara dos Deputados, subscrito por, no mínimo, um por cento do eleitorado nacional, distribuído pelo menos por cinco Estados, com não menos de três décimos por cento dos eleitores de cada um deles.

$\checkmark 10$ O projeto de lei de iniciativa popular deverá circunscrever-se a um só assunto.

$\$ 20$ O projeto de lei de iniciativa popular não poderá ser rejeitado por vício de forma, cabendo à Câmara dos Deputados, por seu órgão competente, providenciar a correção de eventuais impropriedades de técnica legislativa ou de redação.

Art. 14.A Câmara dos Deputados, verificando o cumprimento das exigências estabelecidas no art. 13 e respectivos parágrafos, dará seguimento à iniciativa popular, consoante as normas do Regimento Interno. 
UBERGUE RIBEIRO JUNIOR

Ao aprofundar ainda mais o exame de tudo o que está sendo dito até o presente momento, imperioso é perquirir as bases utilitárias do $\$ 1^{\circ}$ do art.61 da Constituição, quando reserva algumas matérias à iniciativa privativa do Presidente da República.

\section{1 $O$ art.61, $\S^{\circ}$, da Constituição} e o sistema de freios $e$ contrapesos.

$\mathrm{O}$ art.61, $₫ 1^{\circ}$,da Constituição é uma norma típica do sistema de freios $e$ contrapesos, e como tal, visa atenuar ou elidir possíveis interferências de outros poderes em assuntos que, a priori, a Constituição deixou a cargo de um poder ou de uma autoridade.

Tal consideração é válida não apenas em relação ao $₫ 1^{\circ}$ do art. 61 , mas também a todas as normas que estabelecem competências, reservam matérias e compartilham atribuições. Se o princípio da separação de poderes tem tamanha dimensão em nosso ordenamento - chegando até mesmo a ser cláusula pétrea (art. $\left.60, \int 4^{\circ}, I I I\right)-, 0$ mínimo que se pode fazer em defesa desse princípio é objetivar o patrocínio de normas que visem sempre o equilíbrio, evitando-se, por esta forma, as mútuas e indesejadas interferências entre os poderes, e por conseguinte, entre suas autoridades.
Frise-se bem este último enunciado: "evitar interferências entre poderes, e, por conseguinte, entre suas autoridades". Esse destaque é importante, porque todo o sistema de reservas, iniciativas, competências e atribuições de que trata a Constituição é relacionado a instâncias de poder oficialmente constituidas, ou seja, todas as distinções são feitas em relação a poderes e autoridades. Esta é a regra. E assim é com a intervenção federal (art. 36, incisos I a IV), com o sistema de distribuição de competências (arts. 21 a 24), com a emenda constitucional (art. 60, incisos I, II e III), com as ações declaratórias de inconstitucionalidade (art.103, incisos I a VI) ${ }^{11}$ e constitucionalidade (art.103, $\$ 4^{\circ}$ ), e (por que não dizer também?), com a iniciativa das leis (art. 61).

Entretanto, o que não pode ser olvidado é que o art. 61, caput, e por conseqüência, o seu $₫ 2^{\circ}$, contém um dado novo, uma singularidade, uma exceção que nenhum desses citados dispositivos contém: o cidadão, e com ele, a possibilidade de exercício de um instrumento de soberania popular.

Dessa forma, se o art. 61, que de um modo geral é uma norma típica do sistema de freios e contrapesos $\left(\$ 1^{\circ}\right)$, traz (no caput e no $\$ 2^{\circ}$ ) uma hipótese excepcional de legitimação (iniciativa

11 Neste dispositivo, as únicas exceções, bem pontuais, são o Conselho Federal da Ordem dos Advogados do Brasil (inciso VII), partido político com representação no Congresso Nacional (inciso VIII) e confederação sindical ou entidade de classe de âmbito nacional (inciso IX). Veja que em nenhuma dessas exceções, o cidadão comum - o povo - foi contemplado. Este tratamento diferenciado, ele, o cidadão, só recebeu no art.61 da Constituição. 
popular), fugindo, portanto, à regra adotada no bojo de toda a Constituição - que ao estabelecer o sistema de reservas, iniciativas, competências $e$ atribuições, leva sempre em conta o equilíbrio entre os poderes e autoridades a eles pertencentes - fica mais do que comprovada a tese, segundo a qual os cidadãos, dentro do referido dispositivo (art.61), possuem um status constitucional diferenciado, como um verdadeiro plus ao sistema geral, não podendo, conseqüentemente, receber o mesmo tratamento e as mesmas restrições das demais autoridades co-legitimadas em relação às matérias reservadas à iniciativa do Presidente da República.

Com tudo isso, vai ficando clara a idéia de que a ressalva contida no $₫ 1^{\circ}$ do art. 61 da Constituição deve ser interpretada apenas em relação às autoridades constituídas, e não aos cidadãos, quando reunidos nos termos do $\$ 2^{\circ}$ do mesmo artigo.

O corolário dessa assertiva é que dentro do art. 61 e seus $\$ \$ 1^{\circ}$ e $2^{\circ}$ vão existir duas situações inconfundíveis, e que, por serem desiguais, não poderão receber o mesmo tratamento. Assim, não seria nenhuma impropriedade, a partir do disposto acima, distinguir iniciativa potestativa de iniciativa popular, a primeira, como sendo a iniciativa dos poderes oficiais, e a segunda,como manifestação legítima do povo organizado, conseqüência máxima da soberania popular.

Neste sentido, se a iniciativa potestativa e a iniciativa popular são duas situações distintas e inconfundíveis, não restam dúvidas de que devem receber, também, tratamentos diferenciados. Outrossim, não é porque duas situações distintas integram um mesmo dispositivo, que elas deverão ter a mesma interpretação, daí porque, é preciso reconhecer que dentro da lógica do art.61 e seu $\$ 1^{\circ}$ existe uma exceção que não pode ser alijada, qual seja, a de que as reservas de iniciativa do Presidente da República não são extensivas aos cidadãos.

Por falar em exceção, note-se que esta exceção não é um mero desvio a um dispositivo ou a uma simples regra ou padrão, até porque esta exceção não foi concebida através de uma observação isolada do art.61, mas sim, através de uma interpretação conjuntural, aberta, globalizante, que conjuga os vários princípios, valores e fundamentos constitucionais diluídos ao longo de toda a Constituição. Por isso é que o intérprete não deve buscar essa exceção numa lógica fechada e que tenha como parâmetro apenas o texto do art.61. Se ele fizer isso, ou seja, se tomar a decisão de se enclausurar dentro da lógica do próprio artigo, com toda a certeza, não conseguirá atingir o dado hermenêutico capaz de o levar ao encontro dessa exceção.

\subsection{Poder discricionário, legitimidade e soberania popular.}

É preciso não perder de vista que no contexto de toda essa construção jurídica não vai haver nenhum des- 
respeito aos poderes do Presidente da República. $O \$ 1^{\circ}$ do art. 61 , além de sua inegável acuidade ao sistema de freios e contrapesos, tem o sentido de dar ao Presidente todas as condições de utilização de seu poder discricionário, para que ele, avaliando a conveniência e a oportunidade, possa finalmente decidir qual o melhor momento para enviar à Câmara dos Deputados um projeto de lei de sua iniciativa privativa.

Em verdade, não vai ser necessário que o Presidente da República passe doravante a medir forças com os cidadãos. Essa "medição de forças", ou melhor, esse "jogo de poder para quem pode ou não pode" tem que estar restrito tão-somente às autoridades constantes do caput do art.61, e não aos cidadãos.

A iniciativa popular pode ainda significar uma espécie de termômetro da sociedade, mostrando ao próprio Presidente da República o que foi idealizado como prioridade pelos cidadãos $^{12}$, $\mathrm{e}$ isso, data máxima vênia dos que pensam de modo contrário, não significa nenhum desprestígio ao poder discricionário do Presidente, nem muito menos, uma afronta ao sistema de freios e contrapesos.

Assim, se o Presidente da República, por alguma razão, achou que não havia conveniência e oportunidade para apresentar um projeto de lei de sua iniciativa, os cidadãos, mesmo com todas as dificuldades que rodeiam a concretização da iniciativa popular, poderiam muito bem demonstrar ao Chefe do Executivo (que não tem o poder absoluto nem o dom da infalibilidade) que o seu julgamento estava equivocado.

Dessa forma, se com base no dispositivo acima referido, um Deputado ou Senador, por exemplo, encontra barreiras constitucionais (sistema de freios e contrapesos) para propor um projeto de lei que verse sobre alguma matéria privativa do Presidente da República, essas mesmas barreiras não irão servir para os cidadãos. $\mathrm{E}$ isso por uma razão muito simples: a iniciativa popular detém uma certa legitimidade ${ }^{13}$, justamente por advir da soberania popular, que nenhum outro projeto, em tese, poderia ter.

Neste conspecto, não se pode deixar de fazer um registro ao estudo

12 Mutatis mutandis, experiência parecida acontece com os orçamentos participativos, onde a comunidade elege suas prioridades, indicando, ao governo local, onde e como gostaria de ver aplicado os recursos públicos.

13 [...] a legitimidade [...] levanta o problema de fundo, questionando acerca da justificação e dos valores do poder legal. A legitimidade é a legalidade acrescida de sua valoração. [...] A legalidade de um regime democrático, por exemplo, é o seu enquadramento nos moldes de uma constituição observada e praticada; sua legitimidade será sempre o poder contido naquela constituição, exercendo-se de conformidade com as crenças, os valores e os princípios da ideologia dominante, no caso a ideologia democrática." Bonavides, Paulo. Ciência política. $10^{a}$ edição. São Paulo: Malheiros, 2005, p.112. 
de Paulo Bonavides intitulado $A$ despolitização da legitimidade, onde o citado professor chama a atenção para “[...] o processo de despolitização ou de neutralização de que esse conceito vem constantemente padecendo; uma despolitização tão profunda que acabou por descaracterizá-lo, ao fazêlo indiferente a valores, vazio e, por conseqüência, inócuo. Do ponto de vista da acção política acaba sendo também um conceito inútil ou inaplicável à práxis institucional. Não entra assim no universo efervescente e dinâmico de algumas modalidades contemporâneas de sociedade, inclinadas a quebrantarem o status quo ou a ordem estabelecida". ${ }^{14}$

É preciso atentar para esse fenômeno, já que a legitimidade é pressuposto essencial para um regime democrático. Um governo calcado na premissa da democracia tem que ser, acima de tudo, um governo legítimo. Legitimidade e poder são conceitos que caminham lado a lado numa democracia, e por tal razão, quando o conceito de legitimidade começa a perder força - muita vezes sendo confundido com a mera legalidade - é preciso haver uma reflexão.

A idéia que se quer construir para a iniciativa popular, além de estar consoante aos propósitos da legalidade - até porque a interpretação aqui defendida não traz nenhum dado de antinormatividade ou antijuridici- dade - atende também aos de legitimidade. Considerar que os cidadãos através da iniciativa popular estariam no mesmo patamar dos demais legitimados, ou seja, submetê-los às mesmas regras das demais autoridades, é o mesmo que reduzi-los, juntamente com a iniciativa popular, a um reflexo de mera e distorcida legalidade, em prejuízo a todos os demais aspectos axiológicos (de legitimidade) que compõem os institutos da democracia participativa.

A interpretação de que as reservas do $\$ 1^{\circ}$ do art.61 não são aplicáveis à iniciativa popular, até mesmo sob o ponto de vista da legitimidade, tem coerência.Admitir esta interpretação como válida, como também, reconhecer que autoridades e cidadãos não possuem o mesmo status constitucional para efeito do art.61 significa retomar a distinção entre legalidade e legitimidade, e mais, significa resgatar o próprio conceito de legitimidade, afastando-o do vazio e da indiferença que em hoje ele se encontra, segundo o alerta de Paulo Bonavides.

De uma maneira ou de outra, o fato é que os dois pressupostos em que se baseia o $\$ 1^{\circ}$ do art.61 para fazer suas reservas - a) evitar que os outros poderes interfiram em assuntos que, a princípio, cabem ao Poder Executivo através de seu chefe maior, $e b$ ) preservar o poder discricionário do Presidente da República, no sentido

14 Idem. A Despolitização da Legitimidade. Separata da Revista "O Direito", ano $125^{\circ}$, Lisboa, 1993, p.61. 
de que este decida a oportunidade e conveniência para apresentar um projeto de lei - não irão sofrer nenhum prejuízo com a interpretação ora sugerida, tendo em vista que os cidadãos, não são, e nunca foram, uma ameaça às matérias privativas do Presidente da República. Se foi vontade do legislador constituinte originário prever a possibilidade de os cidadãos apresentarem um projeto de lei, então que se reconheça esse poder de iniciativa em sua real dimensão, não o subjugando aos aspectos restritivos de um dispositivo $\left(\$ 1^{\circ}\right.$ do art.61) em detrimento ao fundamento maior de que todo o poder emana do povo, e que pode ser exercido diretamente por ele nos casos da Constituição.

Ora, só há soberania popular onde existe Estado Democrático de Direito, onde existe o núcleo principiológico de que todo o poder emana do povo. ${ }^{15}$ Só há iniciativa popular, quando a Constituição de um país prevê que o povo, titular desse poder, pode exercê-lo (democracia participativa), através dos instrumentos que especifica.Destarte, se a Constituição optou por um instrumento de soberania popular (iniciativa popular) para legitimar a presença do cidadão no contexto geral do art.61, nem o Presidente da República, com suas iniciativas privativas, pode estar acima desse poder.

Se o poder do povo é soberano (soberania popular), é porque esse poder tem um atributo, uma qualidade, qual seja, a de não reconhecer nenhum outro maior do que ele. Ao contrário dos cidadãos, cada membro isolado do Congresso Nacional tem o poder de apresentar um projeto de lei, tendo em vista uma representação que nasceu da vontade popular. Mas o poder soberano quem tem é o povo e, sendo titular de um poder como este, nada justifica que receba restrições, principalmente, quando se sabe que essas restrições foram estabelecidas como meio de equilibrar os poderes e iniciativas das autoridades constituídas, conforme já mencionado.

Noutro sentido, a concretização dessa interpretação levaria o povo a não ficar na dependência de seus mandatários, como também, a não ficar refém das filigranas de ordem

$15^{\prime \prime}$ Admissível reconhecer, a partir de tal compreensão, que o poder provém do povo e deve ser exercido em seu interesse, donde emana o pressuposto básico da legitimidade democrática, baseada na autonomia da vontade coletiva. A igualdade estabelecida pela ideologia liberal relaciona-se com a despersonalização do poder que não mais pode ser exercido ao arbítrio do governante, cujas ações são controladas pelo Parlamento. $O$ poder e as relações sociais em geral deixaram, neste novo ideário, de se entendidos a partir de um fundamento transcendental, passando a ter sua legitimidade explicada com base na dinâmica interna. Por outras palavras, o poder passou a ser legitimado pelo princípio da autonomia coletiva ou soberania popular." ROCHA, Maria Elizabeth Guimalhães Teixeira. Limitação dos mandatos legislativos. Uma nova visão do contrato social. Porto Alegre: Sérgio Antônio Fabris Editor, 2002, p.226-227. 
formal para fazer prevalecer a sua vontade, já que para isso, poderia dispor da iniciativa popular, seja qual for a matéria versada no projeto de lei ordinária ou complementar.

A referência a essas "filigranas" é justificada mediante a observação de algumas discussões em torno do primeiro projeto de lei brasileiro, fruto de iniciativa popular,que dispõe sobre o Sistema Nacional de Habitação de Interesse Social (SNHIS), cria o Fundo Nacional de Habitação de Interesse Social (FNHIS) e seu Conselbo Gestor. ${ }^{16}$

Em resumo, o que os cidadãos subscritores da iniciativa popular querem é criar um sistema nacional de habitação de interesse social que permita o acesso aos menos favorecidos economicamente, a um direito que, no final das contas, é um direito fundamental. No entanto, não há dúvidas de que para viabilizar um conceito sistemático dessa natureza, seria mais do que necessário erigir um centro de decisões e competências - órgão público - mas que terá, dentro do objetivo geral do projeto,o caráter de uma instância burocrática meramente reflexa, como se fosse apenas um suporte oficial à consecução do direito fundamental (moradia), posto no projeto de lei.

Chegando a esse ponto, é preciso indagar: qual interpretação estaria mais associada aos princípios, valores e fundamentos constitucionais? A que condena um projeto de lei de estirpe tão nobre, apenas porque há a previsão reflexa de um órgão público, e que por tal fato,o projeto seria inconstitucional tendo em vista o disposto no art.61, $\S 1^{\circ}$, inciso II, alínea "a", ou a que conjuga esse mesmo dispositivo dentro de seu espectro maior, reduzindo tal restrição à exata medida que ela merece? De acrescer, se o sistema constitucional reconhece uma série de princípios, valores e fundamentos, e mais, se garante aos cidadãos $o$ direito fundamental de morar com dignidade, pergunta-se: qual dessas interpretações estaria mais conforme a Constituição?

Daí porque a necessidade de se avalizar o raciocínio jurídico que até então vem sendo defendido. Se a deci-

16 A situação do referido projeto de lei, aliás, foi a grande incentivadora para a construção de uma base doutrinária que garantisse a total desvinculação da iniciativa popular com as matérias privativas do Presidente da República, constantes do $\$ 1^{\circ}$ do art.61. Por sugestão da Subchefe adjunta Paula Ravanelli Losada, proferi um parecer no âmbito da Subchefia para Assuntos Jurídicos da Casa Civil da Presidência da República, onde tive a oportunidade de construir esta interpretação em contraposição às alegativas de inconstitucionalidade por vício de iniciativa advindas do Senado Federal. O referido projeto de lei, é bom registrar, está no Congresso Nacional desde 1991, e no que tange às questões jurídicas, recebeu parecer favorável das respectivas comissões (CCD), sendo, após inúmeras discussões (principalmente no Senado), aprovado à unanimidade por esta Casa em 24/05/2005. Apenas a título ilustrativo registre-se que o segundo projeto oriundo de iniciativa popular versava sobre o combate à corrupção eleitoral, e hoje é a Lei n. ${ }^{\circ} 9840$ de 28/09/2000. 
são do intérprete não for a de buscar uma interpretação aberta, sistemática e conjuntural para o art.61 da Constituição, isto é, se a sua vontade for a de permanecer constrito a uma visão gramatical e não exauriente deste dispositivo, certamente tal escolha estará ceifando todos os valores jurídicos que inspiram a construção do nosso ordenamento. ${ }^{17}$

Além do mais, a escolha por uma interpretação mais vanguardista $e$ menos conservadora não é nenhuma quimera. Ela é um dado jurídico posto, objetivo, e, portanto, ao alcance de todo e qualquer hermeneuta. De fato, não há nenhuma razão ou sentido para que essa escolha não seja em função de uma interpretação progressista e sistemática, conforme os verdadeiros ditames da Constituição. Por mais que exista um aspecto formal, que num primeiro momento possa levar o hermeneuta a uma interpretação restritiva, basta considerar a Constituição como um todo - a) princípios e fundamentos: art. $1^{\circ}, I I, I I I, V$ e parágrafo único e art. $2^{\circ}$; b) soberania popular:art.14, art.61, caput, $\sqrt{ } 2^{\circ}$; c) regra geral de repartições de atribuiçôes e competências: art.36, incisos $I$ a IV, arts. 21 ao 24, art.60, incisos I, II e III, e art.103, incisos I a VI, $e \int 4^{\circ}$ - para se chegar à conclusão de que a iniciativa popular não sofre limitações em relação às reservas de iniciativa constantes do $\$ 1^{\circ}$ do art.61 da Constituição.

\section{A iniciativa popular e sua interpretação sistemática.}

A busca por uma interpretação sistemática passa por uma espécie de conjugação entre o art. $61, \$ \$ 1^{\circ} \mathrm{e}$ $2^{\circ}$ com os arts. $1^{\circ}$, inciso II, III, V, parágrafo único, e 14, inciso III, todos da Constituição:

Art. 61. A iniciativa das leis complementares e ordinárias cabe a qualquer membro ou Comissão da Câmara dos Deputados, do Senado Federal ou do Congresso Nacional, ao Presidente da República, ao Supremo Tribunal Federal, aos Tribunais Superiores, ao Procurador-Geral da República e aos cidadãos, na forma e nos casos previstos nesta Constituição.

$\int 1^{\circ}$ - São de iniciativa privativa do Presidente da República as leis que:

(...)

17 Em total consonância com o tema, anota Paulo Bonavides:"Nada, porém, mais falso e errôneo, infenso aos progressos da Hemenêutica constitucional de nosso tempo e, ao mesmo passo, nada mais hostil e desrespeitoso à Constituição do que decretar uma inconstitucionalidade onde, na verdade, o que existe é a legítima e fundamental observância do mais preclaro princípio da nossa ordem jurídica, a saber, o princípio da soberania popular." E mais adiante diz ainda o citado mestre: "Como se sabe, a lesão a um princípio é, juridicamente, no constitucionalismo contemporâneo, a ofensa das ofensas. E, se o princípio violado for aquele constante dos arts $1^{\circ}$ e 14 da Constituição, continuar a postergá-lo é o mesmo que decretar a queda da Lei Maior ou desferir um golpe de Estado silencioso e ob-reptício, como se vem fazendo, de último, nos fundamentos da democracia". Paulo Bonavides, teoria constitucional da democracia participativa, ob.cit. p.125 e 130. 
$\int 2^{\circ}$ - A iniciativa popular pode ser exercida pela apresentação à Câmara dos Deputados de projeto de lei subscrito por, no mínimo, um por cento do eleitorado nacional, distribuído pelo menos por cinco Estados, com não menos de três décimos por cento dos eleitores de cada um deles.

Art. $1^{\circ}$.A República Federativa do Brasil, formada pela união indissolúvel dos Estados e Municípios e do Distrito Federal, constitui-se em Estado Democrático de Direito, e tem como fundamento:

II - a cidadania

III - dignidade da pessoa humana

\section{$\mathrm{V}$ - pluralismo político}

Parágrafo único. Todo o poder emana do povo, que o exerce por meio de representantes eleitos ou diretamente, nos termos desta Constituição.

Art.14.A soberania popular será exerci- da pelo sufrágio universal e pelo voto direto e secreto, com valor igual para todos, e, nos termos da lei, mediante:

\section{(..)}

III - iniciativa popular.

$\mathrm{O}$ art.61 faz referência ao cidadão, deduzindo que ele poderá, através de iniciativa popular, apresentar um projeto de lei desde que obedecido os requisitos do $\$ 2^{\circ}$ que, aliás, são reconhecidamente rigorosos ${ }^{18}$. Iniciativa popular, por conseqüência, além de ser um instituto originário da soberania popular, representa um dos postulados mais valiosos do que vem a ser cidadania:

À guisa dessas considerações, observe-se como o raciocínio vai, plasticamente, seja qual for o sentido, da cidadania (art. $1^{\circ}$, II) até o cidadão (art.61, caput), e do cidadão (art.61, caput) até a cidadania (art. $1^{\circ}$, II), como uma cadeia lógica de estruturação incontestável dentro do nosso regime.

18 É praticamente unanimidade entre os autores o quanto o legislador constituinte impôs barreiras ao exercício da iniciativa popular.Alguns chegam até a sugerir que a iniciativa popular seria uma espécie de "adorno" constitucional, instituto de nenhuma efetividade. Outros, como é o caso de Mônica de Melo afirma: "Exigir um quorum de tão difícil alcance é minar a possibilidade de se exercer o direito político constitucional, vedando por vias transversas a possibilidade de participação. Diante dessa contingência, torna-se mais fácil conseguir que um deputado ou senador apresente em seu próprio nome o projeto pretendido". (Mônica de Melo, ob. cit. p.194). Não há dúvidas de que esses requisitos são exageradamente rigorosos. No entanto, apesar de todas essas dificuldades é preciso reconhecer dois pontos: 1) a iniciativa popular, apesar de tímida, já conseguiu sair do papel, e 2) não obstante ser mais fácil conseguir o patrocínio de Deputados ou Senadores para a apresentação do projeto poderá, surgir uma situação concreta específica - como no caso do primeiro projeto de lei brasileiro de origem popular - onde os parlamentares, pela matéria posta em discussão, não poderão assumir a iniciativa do projeto. Traduzindo essa assertiva, se os cidadãos fossem esperar a iniciativa de algum parlamentar, tal projeto certamente estaria fadado ao insucesso, (leia-se, inconstitucionalidade por vício de iniciativa), já que a previsão de criação de um órgão público, ainda que de natureza reflexa, praticamente inviabilizaria todo o projeto, tendo em vista o que dispõe o art.61, $₫ 1^{\circ}$, alínea " $\mathrm{e}^{"}$, da Constituição. 


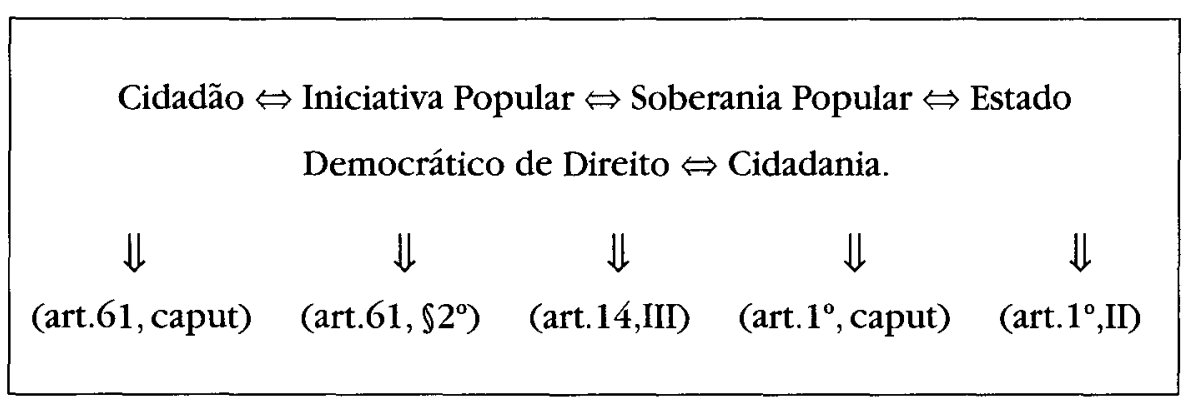

Dessa forma, se a cidadania é um fundamento de nossa república, e se o seu conceito passa pela "participação ativa e direta do cidadão nos rumos e nas decisões políticas do seu Estado", fica claro que não se pode tolher um fundamento deste jaez (art. $1^{\circ}$,II), através de uma simples regra reservista (art.61, $\left.₫ 1^{\circ}\right)$.

Além do mais, se 0 art. $1^{\circ}$ da Constituição - que é o dispositivo que "fotografa", a natureza ôntica deste país, indicando que tipo de Estado nós formamos (federação), que forma de governo nós escolbemos (república), e os alicerces do regime que nós conquistamos (democracia) - diz que a cidadania é fundamento explícito de toda essa construção jurídica, jamais se poderia imaginar alguma restrição a essa iniciativa popular de participar e de se fazer ouvir nas decisões políticas do país. ${ }^{19}$

Essa vontade de participar cada vez mais, a propósito, é o que as doutrinas mais progressistas têm procurado buscar através de um conceito de democracia participa-

19 Demonstrando toda sua maturidade política, Maria Victoria de Mesquita Benevides consagra: "(...) a cidadania ativa através da participação popular é aqui considerada um princípio democrático, e não um receituário político, que pode ser aplicado como medida ou propaganda de um governo, sem continuidade institucional. Não é "um favor" e, muito menos, uma imagem retórica. É a realização concreta da soberania popular, mais importante do que a atividade eleitoral que se esgota na escolha para cargos executivos e legislativos.A participação popular, assim entendida, supera a velha polêmica sobre o "verdadeiro" significado de cidadania ativa na filosofia política, desde o século XVIII - assim como a dicotomia Estado e sociedade civil, vigente até hoje ente liberais e antiliberais. Esta cidadania ativa supõe a participação popular como possibilidade de criação, transformação e controle sobre o poder, ou os poderes". Benevides, Maria Victoria de Mesquita.A Cidadania Ativa. São Paulo: Ática, 1991, p.19.

20 O Prof.Paulo Bonavides diz que há quatro princípios cardeais que compõem a estrutura constitur cional da democracia participativa: o princípio da dignidade da pessoa humana, o princípio da soberania nacional, o princípio da soberania popular e o princípio da unidade da Constituição. Mais adiante, diz ainda o citado mestre: "A democracia participativa é direito constitucional progressivo e vanguardeiro. É direito que veio para repolitizar a legitimidade e reconduzi-la às suas nascentes históricas, ou seja, àquele período em que foi bandeira de liberdade dos povos". Paulo Bonavides, teoria constitucional da democracia participativa, ob cit, p.33. 
tiva $^{20}$, sendo esta a personificação dos novos desideratos da democracia daqui para frente.

O modelo estigmatizado e petrificado de uma democracia apenas representativa não mais convence diante dos novos desafios e exigências de uma sociedade em processo de evolução na ordem democrática. ${ }^{21}$ Se a democracia representativa foi, e ainda é, o pilar central do nosso sistema, hoje mais do que nunca ela deve ser encarada como a raiz, a fonte de uma nova democracia, mais participativa, e, portanto, em mais sintonia com os clamores populares.

A democracia de hoje não é a mesma de 1988, ano de promulgação da Constituição, como a de 1988 não era igual a de 1946, data da última Constituição democrática. Dentro do espírito dialético mencionado por JoséAfonso da Silva,"que vai rompendo contrários e incorporando novos conteúdos no processo evolutivo", ${ }^{22}$ é preciso que também se absorvam as novas interpretações, ou melhor, as interpretações que levem mais em conta as normas genésicas e o espírito sistemático da Constituição, e não apenas as leituras estanques de um ou outro dispositivo.

Como é cediço em qualquer fonte jurídica, um princípio, um fundamento, vale mais do que qualqu er artigo isolado. Não apenas isso, cada dispositivo, isolado ou não, tem que trazer consigo o espírito do princípio ou fundamento que o legitima, razão por que não se pode jamais interpretar um simples parágrafo de um artigo $\left(\$ 1^{\circ}\right.$ do art.61) em detrimento a esse

21 Dentro desta perspectiva, valiosas são as observações de José Afonso da Silva, quando diz: "Democracia é conceito histórico. Não sendo por si um valor-fim, mas meio e instrumento de realização de valores essenciais de convivência humana, que se traduzem basicamente nos direitos fundamentais do homem, compreende-se que a historicidade destes a envolva na mesma medida, enriquecendo-lhe o conteúdo a cada etapa do evolver social, mantido sempre o princípio básico de que ela revela um regime político em que o poder repousa na vontade do povo. Sob esse aspecto, a democracia não é um mero conceito político abstrato e estático, mas é um processo de afirmação do povo e de garantia dos direitos fundamentais que o povo vai conquistando no correr da histórica". [...] "Por isso é que a democracia da antiguidade grega não é a mesma dos tempos modernos; nem a democracia burguesa capitalista corresponde à democracia popular". SILVA, José Afonso da. Curso de Direito Constitucional Positivo.19 $9^{\mathrm{a} e d i c ̧ a ̃ o . ~ S a ̃ o ~ P a u l o: ~ M a l h e i r o s, ~ 2000, ~ p .130 . ~}$

22 Coroando de vez a idéia do trecho anterior, José Afonso ainda leciona: "Finalmente, os que reclamam que a democracia nunca fora realizada em sua pureza em lugar algum concebem-na como um conceito estático, absoluto, como algo que há que instaurar-se de uma vez e assim perdurar para sempre. Não percebem que ela é um processo, e um processo dialético que vai rompendo os contrários, as antíteses, para, a cada etapa da evolução, incorporar conteúdo novo, enriquecido de novos valores. Como tal, ela nunca se realiza inteiramente, pois, como qualquer vetor que aponta a valores, a cada nova conquista feita, abrem-se outras perspectivas, descortinam-se novos horizontes ao aperfeiçoamento humano, a serem atingidos." Ibidem, p. 133. 
princípio ou fundamento integrante da base ontológica estatal.

Com efeito, a partir da concretização desse caminho interpretativo, o povo não precisará mais ficar na dependência de seus mandatários e das excessivas filigranas de ordem formal para fazer com que os seus clamores sejam diretamente ouvidos, já que para isso, poderá dispor de iniciativa popular,seja qual for a matéria versada no projeto de lei.

\section{A iniciativa popular sob a ótica da nova hermenêutica constitucional.}

A concepção de uma interpretação lógico-sistemática, conforme visto, é perfeitamente possivel. Isso porque, não obstante todo o respeito pela interpretação lógico-restritiva, o próprio sistema constitucional, ou melhor, a própria Constituição, mostra todos os caminhos possiveis para um entendimento menos restritivo em relação à iniciativa popular. Resumindo, se a leitura isolada do art.61 não fornece todos os elementos para a melhor compreensão desse instituto, o "sistema" como um todo, dá essa condição.

No entanto, apesar desta concepção de sistema, há quem possa sugerir que foi o "sistema" que quis fazer a exceção, excluindo algumas matérias da iniciativa geral $\left(\operatorname{art} .61, \S 1^{\circ}\right)$, e por conseguinte, da iniciativa popular.

No caso específico, o que é preciso considerar é que há uma grande diferença entre "criar uma exceção" e "poder criar uma exceção".A decisão de deixar a iniciativa de algumas matérias apenas para o Presidente da República era, e ainda é, uma opção política plenamente plausível.Quanto a isso não há o que discutir.Agora, essa mesma decisão política em nenhuma hipótese poderá absorver os cidadãos, sob pena de criar uma total incongruência entre o art.61, $₫ 1^{\circ}$, com os arts. $1^{\circ}$ e 14 da Constituição, ou seja, se o constituinte optou por contemplar a participação do cidadão no caput do art.61, é a própria inspiração democrática, aliada aos seus valores e princípios, que impede que essa exceção seja extensiva aos cidadãos e à iniciativa popular.

Apesar de não estar manifesto de forma expressa, o que o "sistema" fez para evitar essas incongruências foi criar, em verdade, duas exceções ao invés de apenas uma.Assim, quando ele consignou a primeira exceção (matérias de iniciativa privativa do Presidente da República, cf. o art.61, $\$ 1^{\circ}$ ), de maneira contínua e implícita também realizou uma segunda exceção, qual seja, a de que a primeira exceção seria destinada apenas às autoridades constituídas, e não aos cidadãos.

De toda maneira, apesar de o sistema conter todos os elementos para uma interpretação mais condizente com a áura democrática da Constituição, acredita-se que esta mesma interpretação também encontraria 
sua razão de ser numa dimensão mais acadêmica e vanguardista.

Se para alguns o sistema não seria, de per si, capaz de legitimar a interpretação aqui defendida, o mesmo não aconteceria com os primados da nova hermenêutica constitucional de que fala Paulo Bonavides: "A construção teórica da democracia participativa (incluindo aí a iniciativa popular) no âmbito jurídicoconstitucional demanda o concurso de elementos tópicos, axiológicos, concretistas, estruturantes, indutivos e jusdistributivistas, os quais confluem todos para inserir num círculo pragmático-racionalista o princípio da unidade material da Constituição, o qual impetra, de necessidade, para sua prevalência e supremacia, uma hermenêutica da Constituição ou Nova Hermenêutica Constitucional, conforme tantas vezes, em inumeráveis espaços textuais, neste e noutros escritos, já referimos debaixo dessa mesma denominação, tendo por desígnio metodológico e nomeclatural distingui-la da hermenêutica antiga e clássica." ${ }^{23}$

A moderna interpretação constitucional, segundo o citado mestre, é decorrente do inconformismo de alguns juristas com a sói aplicação do positivismo lógico-formal, razão pela qual estes foram em busca do sentido mais profundo da Constituição, como meio de fazer uma ligação mais palpável entre direito e sociedade. ${ }^{24}$

Nessa linha de oposição ao positivismo fechado pode-se mencionar o método integrativo ou científico-espiritual, como também a tópica constitucional, e a partir dela, o método de concretização que desembocou em várias diretivas, como por exemplo, a teoria estruturante de Friedrich Muller e a teoria dos intérpretes da Constituição de Häberle.

Registre-se que, em todas essas linhas de raciocínio contra a exacerbação do positivismo, a interpretação aqui consubstanciada para a iniciativa popular encontra respaldo e fundamento. Seja qual for a predominância da perspectiva, como essa interpretação busca o equilíbrio, a razão, a essência, e principalmente a concretização verdadeira de um instituto do porte da iniciativa popular, ou melhor, como essa interpretação, ao contrário da lógica positivista, visa agregar vários elementos, ela passa a exprimir um insofismável ponto de convergência, valendo-se não de uma teoria, mas do concurso delas, no exato sentido mencionado por Paulo Bonavides, no que tange à construção teórica da democracia participativa.

23 PAULo Bonavides, teoria constitucional da democracia participativa, ob.cit. p. 42.

24 Idem, Curso de direito constitucional, $15^{\wedge}$ edição. São Paulo: Malheiros, 2004 , p.476. 


\subsection{Método integrativo ou} científico-espiritual, a tópica constitucional e a concretização estruturante de Friedrich Muller.

Não foi uma, mas várias, as vezes que neste estudo frisou-se a importância da "unidade" e do "espírito" da Constituição. Uma norma constitucional não pode ser considerada de modo isolado, dentro de uma lógica fechada e de inspiração puramente positivista. É, pois, nessa acepção que Rudolf Smend, com base numa ótica sistêmica e espiritualista, concebe o método científico-espiritual, começando, portanto, “[...] com essa visão de conjunto, essa premissa fundamental de que a Constituição há de ser interpretada sempre como um todo, com percepção global ou captação de sentido. Sentido sempre geral e de totalidade, que coloca tudo mais sub specie do mesmo conjunto [...]". ${ }^{25}$ Essa concepção, como se vê, anda lado a lado com a interpretação sistemática,identificando, no próprio sistema, as respostas para os problemas constitucionais.

Saindo da idéia de sistema hierárquico-axiológico, observa-se que a concepção de iniciativa popular defendida neste estudo também não encontraria dificuldade de adequação a um procedimento tópico.

A cognição através da tópica não é nenhuma novidade dos tempos atuais. Vários foram os pensadores que a idealizaram e que a aplicaram em seus estudos filosóficos. Com efeito, como informa Paulo Bonavides, se a tópica já era conhecida, coube a Theodor Viehweg retomar essa linha de pensamento e aplicá-la ao universo jurídico. ${ }^{26}$

"Pensar o problema" é a raiz desta técnica jurídica de práxis, que busca uma teoria de argumentação volvida primariamente para o caso concreto. ${ }^{27}$ Essa proposta, num primeiro momento, se opôs de maneira cabal ao pensamento sistêmico, direção esta que em nada contribuiu para o alcance dos seus verdadeiros propósitos.

Na verdade, se o objetivo da tópica, antes de tudo, era criar uma base doutrinária sólida contra a insuficiência e as elucubrações puritanas do positivismo, não poderia ela partir do mesmo pressuposto discriminatório e

25 Paulo Bonavides, Curso de Direito Constitucional, ob.cit., p.478.

26 Aliás, como ainda bem menciona Paulo Bonavides:"O prestígio da tópica em toda a Alemanha logo se fez sentir com a adesão de três civilistas eminentes - Wieacker, Esser e Coing - seguida do apoio de constitucionalistas de peso, como Schneider e Ehmke, relatores do tema "Princípios de Interpretação Constitucional", exposto na assembléia de 1961 dos professores de direito público daquele país. Inclinaram-se também para a tópica, nomeadamente para uma teoria material da Constituição, construindo estradas próprias com o propósito de alcançar objetivos semelhantes, juristas da envergadura de Martin Kriele, Peter Häberle, Friedrich Muller e Konrad Hess." Ibidem, p.490.

27 Ibidem, p.490 e 497 
refutar um elemento tão importante como o sistemático. De conseguinte, a partir dos estudos de Martin Kriele a antinomia antes existente entre tópica e sistema deixou de existir, passando a tópica a levar em conta todos os elementos possíveis para a resolução do caso concreto.

Trocando o aspecto abstrato da norma por uma perspectiva empírica, nota-se que a interpretação aqui defendida para a iniciativa popular também não haverá de encontrar maiores óbices. $\mathrm{O}$ que se defende neste estudo é que a essência da iniciativa popular não seja tolhida por uma regra restritiva, regra esta que não tem nenhuma aplicabilidade aos cidadãos, mas sim, às autoridades constituídas. Se "pensar o problema" é o lema maior da tópica, é justamente "pensando o problema" através de uma interpretação aberta - levandose em conta cada elemento, isto é, cada topoi: norma, sistema, linguagem, experiência, lógica, etc. -, que a tese ora defendida se fortalece, já que todos esses topois levam o intérprete à conclusão de que as reservas feitas pelo $\$ 1^{\circ}$ do art.61 da Constituição não alcançam a iniciativa popular.

A primazia do "pensar o problema" leva também à concretização, e, por conseguinte, a Friedrich Müller, que percorrendo os mesmos caminhos da tópica - mas com algumas modificações e reparos - "desenvolve um método racionalista de interpretação constitucional, em que procura deixar estruturada uma hermenêutica que permita explicar a Constituição, sem perda de sua eficácia, e como ela realmente se apresenta, com vínculos materiais indissolúveis, fora da própria antinomia tradicional, por onde se operava a separação irremediável entre a Constituição formal e a Constituição material". ${ }^{28}$

A preocupação de Friedrich Müller é desautorizar as críticas em relação à tópica, no sentido de que a abertura promovida por ela não traga uma perda de normatividade à Constituição. Essa preocupação entre a eficácia da norma e o caso concreto (tópica), ou seja, entre a Constituição formal e a Constituição material, segundo Bonavides, leva Müller a considerar que a interpretação-concretização de uma norma transcenda à interpretação do texto, coisa que não acontecia nos métodos clássicos. "Com o concretismo daquele Mestre chega-se a um ponto, conforme já vimos, em que o jurista, ao falar da Constituição, deve esquecer que está falando do texto da Constituição, assim como ao falar da lei deve ter em mente que não é a letra da lei o objeto de sua referência. $O$ verbalismo normativo é de somenos, o realismo extravocabular da norma é tudo, principalmente quando se trata de matéria constitucional, no processo

28 Paulo Bonavides. Curso de Direito Constitucional, ob.cit., p. 498. 
de sua concretização, que abrange funcionamento, reconhecimento e atualidade efetiva". ${ }^{29}$

Sempre na esteira das lições de Paulo Bonavides a respeito de Müller, conclui-se que não é o texto da norma que regula o caso concreto, já que este não contém a normatividade e sua estrutura material concreta. ${ }^{30}$ Aliás, o texto só toma sentido quando posto numa operação ativa de concretização. A par dessa assertiva, por mais que a orientação do positivismo-formal se empenhe em afirmar que o $\rrbracket^{\circ}$ do art.61 engloba todos os co-legitimados do caput, é preciso reconhecer que com essa interpretação simplista não haveria nenhuma identidade do texto da norma com a própria norma, segundo a lição de Müller. Ademais, se houvesse essa identidade - nos moldes apregoados pelos positivistas - estar-se-ia criando um paradoxo constitucional sem precedentes, tendo em vista a inconfundível inspiração democrática de nossa Constituição.

No bojo de toda essa discussão, há ainda um questionamento no $₫ 1^{\circ}$ do art.61 que precisa ser enfrentado dentro dessa perspectiva mencionada por Friedrich Müller. Como se sabe, tal dispositivo diz que aquelas matérias indicadas nas alíneas " $a$ " a " $f$ " são privativas do Presidente da República.Antes de fazer a análise do termo privativo é importante observar que uma parte da doutrina pátria faz referências ao que é privativo e exclusivo, ressaltando a existência de elementos distintivos entre os dois termos.

Sobre o assunto diz José Afonso da Silva: "A diferença que se faz entre competência exclusiva e competência privativa é que aquela é indelegável e esta é delegável. Então, quando se quer atribuir competência própria a uma entidade ou a um órgão com possibilidade de delegação de tudo ou de parte, declara-se que compete privativamente a ele a matéria indicada. Assim, no art.22 se deu competência privativa (não exclusiva) à União para legislar sobre: [...], porque o parágrafo único faculta à lei complementar autorizar os Estados a legislar sobre questões específicas das matérias relacionadas nesse artigo. No art.49, é indicada a competência exclusiva do Congresso Nacional. $O$ art. 84 arrola a matéria de competência privativa do Presidente da República, porque o seu parágrafo único permite delegar algumas atribuições ali arroladas. Mas a Constituição não é rigorosamente técnica neste assunto. Veja-se, por exemplo, que nos arts.51 e 52 traz matérias de competência exclusiva, respectivamente, da Câmara dos Deputados e do Senado Federal, mas diz

29 Ibidem, p.504 e 505.

30 Conforme ainda destaca Paulo Bonavides:" [...] faz-se mister segundo o constitucionalista de Heidelberg pesquisar a estrutura da normatividade, o que significa compreender a concretização da norma como um processo estruturado, a fim de que assim se possa determinar a verdadeira estrutura das normas jurídicas". Ibidem, p.504. 
que se trata de competência privativa. Não é deste último tipo, porque são atribuições indelegáveis". ${ }^{31}$

É claro que esta é uma regra de mera semântica e que não pode ser considerada ou entendida de maneira absoluta. Na verdade, tal distinção é aqui trazida em caráter ilustrativo, apenas para demonstrar que não é o fato de o $₫ 1^{\circ}$ do art.61 trazer o termo "privativo", que toda a interpretação do dispositivo tem que estar em função deste termo, como se ele estivesse acima de tudo e de todos. ${ }^{32}$

Dessa forma, essa distinção semântica é o que menos vai importar diante de tudo o que foi dito até agora. Involuntariamente ou não, a Constituição traçou todos os caminhos para se adotar a interpretação sugerida neste estudo em relação à iniciativa popular. Embora ela não tenha previsto a delegação no art.61 - nos mesmos moldes que fez com os parágrafos únicos do art.22 e 84 - disse que a iniciativa era privativa, e não exclusiva, e mais, abriu uma exceção ao sistema geral de repartição de competências e atribuições, antes destinado apenas aos poderes e autoridades constituídas, para dar ao cidadão (iniciativa popular) um status constitucional diferenciado, permitindo-o ocupar um posto de co-legitimação com as demais autoridades do caput do art.61.

Resumindo, ao mesmo tempo em que a Constituição não segue a regra de consignar o termo privativo, $\mathrm{e}$ logo após permitir expressamente a delegação, ela compensa tal omissão quando prevê a situação excepcional de um instituto de soberania popular como instrumento apto à apresentação de um projeto de lei.

Decerto, a doutrina poderia até questionar, e com razão, a possibilidade de o Presidente da República delegar competência a alguma outra autoridade ante o fato de que a Constituição, apesar de consignar o termo privativo, não trouxe nenhuma hipótese expressa de delegação, como fez com os arts.22 e 84. Com efeito, apesar da aridez doutrinária de se admitir essa possibilidade, é preciso reconhecer também que essa mesma dificuldade restringe-se apenas às autoridades constituídas, $\mathrm{e}$ não aos cidadãos por via da iniciativa popular.

Por fim, observe-se que o termo privativo, nesse caso particular, permite duas leituras: a) para as autoridades, enquanto desacompanhada de uma delegação expressa, constitui um

31 José Afonso, Curso de Direito Constitucional Positivo, ob.cit. p. 482.

32 E isso, sem esquecer que a própria Constituição não é tão precisa em alguns de seus termos, cometendo alguns deslizes, quando, por exemplo, diz que a competência dos arts.51 e 52 é privativa e não exclusiva, ou até mesmo quando fala "demissíveis" ad nutum (v.g .o art.54,II,b) quando o correto seria "exoneráveis". De toda forma, além da semântica não ser um critério tão confível assim, sempre vai haver necessidade de interpretação, e nesse contexto, não se pode transformar um equívoco no paradigma a ser seguido. 
UBERGUE RIBEIRO JUNIOR

verdadeiro empecilho à delegação do Presidente da República; e b) para os cidadãos, significa não exclusividade, razão pela qual, as restrições do $₫ 1^{\circ}$ do art.61 não seriam extensíveis à iniciativa popular.

Com essa diferenciação, encontrase, finalmente, a identidade entre o texto da norma e a norma propriamente dita, conforme sustentado por Friedrich Muller.

\subsection{Um paralelo entre iniciativa popular e a teoria da sociedade aberta dos intérpretes da Constituição de Peter Häberle.}

Como ficou demonstrado em linhas atrás, $o ₫ 1^{\circ}$ do art.61 tem uma intima conotação com o sistema de freios e contrapesos, e por assim dizer, com os poderes e autoridades constituídas, de modo que sua essência está toda voltada para esses participantes formais do processo constitucional. Indo mais além, não seria nenhum exagero dizer que, a priori,é como se a própria Constituição fosse "imaginada" apenas para esses participantes, seja em relação à iniciativa de projetos de lei, seja em relação à interpretação da Constituição.

Insurgindo-se contra essa "oficialização", Häberle, partindo da premissa de Karl Pooper ${ }^{33}$, cria as bases jurídicas para a construção de uma hermenêutica que atenda à sociedade aberta através de um processo de democratização. A partir dessa "sociedade aberta", e valendo-se de uma considerável inspiração tópica, o citado doutrinador ergue o método concretista da "Constituição aberta" ${ }^{34}$, fazendo com que o foco saia dos intérpretes oficiais (sociedade fechada) para alcançar a sociedade aberta dos intérpretes da Constituição. ${ }^{35} \mathrm{~A}$ propósito, diz Peter Häberle: "Até há pouco tempo imperava a idéia de que o processo de interpretação constitucional estava reduzido aos órgãos estatais ou aos participantes diretos

33 "Karl Popper definiu esse moderno modelo social como sociedade aberta, diversa daquela estamental, totalitária da Idade Média e que se modificam e se enriquecem com o tempo, sendo, portanto, dinâmicas. Essa dinamicidade é projetada pelo dissenso integrante dessa própria sociedade, ou seja, por meio do aparente conflito de interesses, de concepções, de pensamentos que fazem com que ela não pare no tempo, mas que se desenvolva continuamente". AMARAL, Rafael Caiado. Peter Häberle e a hermenêutica constitucional. Alcance doutrinário. Porto Alegre: Sérgio Antônio Fabris Editor, 2004. p.118.

34 Bonavides, Paulo, Curso de direito constitucional, $15^{\mathrm{a}}$ edição. São Paulo: Malheiros, 2004, p.465.

35 Importante ainda é consignar a seguinte asseveração do Prof. Paulo Bonavides:"A construção teórica de Häberle parece desdobrar-se através de três pontos principais: o primeiro, o alargamento do círculo de intérpretes da Constituição; o segundo o conceito de intepretação como um processo aberto e público e, finalmente, o terceiro, ou seja, a referência desse conceito à Constituição mesma, como realidade constituída e "publicização" ("verfassten Wirklichkeit und Öffentlichkeit"). Ibidem, p.466. 
do processo. Tinha-se, pois, uma fixação da interpretação constitucional nos "órgãos" oficiais, naqueles órgãos que desempenham o complexo jogo jurídico-institucional das funções estatais". ${ }^{36}$

O caráter propedêutico dessas considerações leva o hermeneuta a perceber que da mesma maneira que a teoria da sociedade aberta dos intérpretes da Constituição prevê um alargamento da legitimidade para a interpretação constitucional - levando-se em conta a desconstrução da exclusividade em relação aos setores oficiais - a idéia contida nesse estudo sobre iniciativa popular também se molda nessa mesma espécie de alargamento.A diferença, ao que parece, é que, enquanto a doutrina se concentra mais no juiz constitucional para aplicar a teoria de Häberle, aqui o ponto nuclear não vai estar no juiz, mas sim no legislador, tendo em vista que nesta linha de raciocínio, a situação vislumbrada é a do cidadão que leva ao legislador - seja qual for a matéria - um projeto de lei que já contenha uma interpretação,interpretação esta, construída por uma parcela da sociedade não-oficial, saindo, portanto, do paradigma da "sociedade fechada dos intérpretes da Constituição para uma interpretação pela e para uma sociedade aberta" ${ }^{37}$.

Assim, com base nessa providência, os cidadãos carimbam definitivamente a sua participação no processo de democratização mencionado por Häberle, e mais, fazem isto através de um dos mais legítimos meios constitucionais.

Importante registrar que tudo isso não é um simples jogo de retórica. Essa subsunção entre a teoria da sociedade aberta dos intérpretes da Constituição e a iniciativa popular já é fato. Exemplo emblemático, repise-se, está no primeiro projeto de lei brasileiro fruto de iniciativa popular - que dispóe sobre o Sistema Nacional de Habitação de Interesse Social (SNHIS), cria o Fundo Nacional de Habitação de Interesse Social (FNHI) e seu Conselbo Gestor - onde os cidadãos, visando à consecução de um direito fundamental (moradia), terminam propondo também a criação de um órgão público para concretizar esse direito que, "a princípio", seria privativo do Presidente da República.

Segundo Häberle, "quem vive a norma acaba por interpretá-la",

36 Häberle, Peter. Hermenêutica constitucional. A sociedade aberta dos intérpretes da Constituição: contribuição para a interpretação pluralista e "procedimental" da Constituição. Tradução Gilmar Ferreira Mendes. Porto Alegre: Sérgio Antonio Fabris Editor, 1997, p. 24.

37 Nas próprias palavras de Häberle: "Nesse sentido, permite-se colocar a questão sobre os participantes do processo da interpretação: de uma sociedade fechada dos intérpretes da Constituição para uma interpretação constitucional pela e para uma sociedade aberta". Ibidem, p. 12-13. 
Ubergue RibeIRo Junior

e nestes termos, é inegável a total congruência entre iniciativa popular e a teoria da sociedade aberta dos intérpretes da constituição, sendo a primeira uma considerável porta de entrada para a concretização da segunda.

Veja que, enquanto foi preciso uma mudança legislativa - Leis n.9.868/99 e 9.882/99 - para "pluralizar o debate constitucional" ${ }^{38}$, e assim, criar as condições precursoras e necessárias para a adoção da teoria da Häberle no Brasil, no que tange à iniciativa popular, basta um exercício de interpretação sistemático, aberto e concretista, que procure e reconheça tudo aquilo que a própria Constituição elegeu como valor e como espírito.

Essa interpretação da iniciativa popular é hoje, não o futuro, mas o presente, ou seja, é a tradução concreta e mais atual da teoria da sociedade aberta dos intérpretes da Constituição.

\section{Aplicabilidade da disjunção de normas e do catálogo tópico dos princípios de interpretação constitucional à iniciativa popular.}

A aproximação da tópica com o direito positivado, trazendo um maior equilíbrio entre Constituição formal e Constituição Material, faz com que se seja possível iniciar uma comparação ente as duas interpretações até aqui mencionadas: a) a interpretação lógico-restritiva ou interpretação fechada, e b) a interpretação lógicosistemática, ou interpretação aberta. Contudo, antes de entrar nesse domínio comparativo, uma boa iniciativa seria trazer para esse estudo as considerações de Gomes Canotilho, sobre a disjunção de normas e o catálogo

38 Importante registrar as palavras de Rafael Caiado Amaral: “No Brasil, todavia, como a vida constitucional não integra ainda a cultura dos brasileiros, não é possível, assim, a aplicabilidade de "A sociedade aberta dos intérpretes da Constituição". Isso se deve ao fato de nosso país ser uma nação subeducada. Não se incutiu na consciência de nós brasileiros o papel e a importância da Constituição nem, tão pouco, os valores fundamentais que ela consagra.Além do que o Estado não cumpre seu papel de defensor e realizador dos preceitos constitucional, criando um estado de desestima constitucional, o que gera, ao invés de uma adesão e um respeito a Constituição, um sentimento de desrespeito e descrença. Muito embora, não se tenha consolidado no Brasil uma cultura constitucional que propiciasse à sociedade aberta participar do processo hermenêutico constitucional, os ventos vindos da Alemanha, soprados por Häberle, no entanto, já chegaram em nosso país. Pode-se constatar tal afirmativa pelas leis $9868 / 99$ e $9882 / 99$, que regulam o procedimento das ações diretas de inconstitucionalidade, declaratória de constitucionalidade e da argüição de descumprimento de preceito fundamental, respectivamente. Essas duas leis reformularam a jurisdição constitucional brasileira pluralizando o debate constitucional, promovendo uma abertura procedimental que englobou a sociedade aberta.A principal inovação trazida pelos referidos instrumentos legais foi o amicus curiae, incorporado ao sistema jurídico brasileiro no art. $7^{\circ}, \$ 2^{\circ}$, da Lei 9868/99". Rafael Caiado Amaral, ob.cit.p. 187. 
tópico dos princípios de interpretação constitucional. ${ }^{39}$

Nesse sentido, começa o mestre português: "É muito corrente, em algumas sentenças do Tribunal Constitucional, a alusão a "fragmentos de normas", a "segmentos de normas", a "articulação de normas". Convém tomar contacto com estes conceitos que, de resto, são também usuais em obras de doutrina sobre "metodologia jurídica", "linguagem jurídica" e "raciocínio jurídico". Além de serem conceitos correntes nos discursos jurisprudenciais e doutrinários, eles constituem importantes instrumentos metódicos no trabalho de interpretação/concretização do texto constitucional". ${ }^{40}$

A partir desse prolegômeno, Canotilho encarta o que chama de disjunção de normas: "Uma só disposição (formulação, enunciado) pode exprimir uma ou outra norma, segundo as diversas possibilidades de interpretação. Tomemos, como exemplo, o art. $24^{\circ} / 1$ da CRP: "A vida humana é inviolável". Esta disposição pode conter, pelo menos, três normas, consoante o significado que the é adscrito: Norma 1:"a vida humana é inviolável desde o momento do nascimento até ao momento da morte"; Norma 2:"a vida humana é inviolável desde o momento da concepção até o momento da morte"; Norma 3: "a vida humana é inviolável desde o momento em que, de acordo com os dados da ciência, começa a haver vida intra-ulterina até o momento da morte". ${ }^{41}$

E prossegue: "Como se vê, não é indiferente, para efeitos de protecção da vida e da punição da interrupção da gravidez, optar-se por uma ou outra interpretação. Podemos representar simbolicamente esta disjunção (D N1? N2? N3?)". ${ }^{42}$

Trazendo a proposição da disjunção de normas para a iniciativa popular, e salvadas as devidas proporções, chega-se ao seguinte esboço demonstrativo:

(D _ N1? N2?)

Art. 61. A iniciativa das leis complementares e ordinárias cabe a qualquer membro ou Comissão da Câmara dos Deputados, do Senado Federal ou do Congresso Nacional, ao Presidente da República, ao Supremo Tribunal

39 Esse mesmo recurso doutrinário foi usado por nós no artigo denominado A Natureza Jurídica do Parquet Especial, onde procuramos trazer uma nova perspectiva para o Ministério Público junto ao Tribunal de Contas, a partir de uma análise conjuntural e diferenciada do art.130 com os arts. $73, \$ 2^{\circ}$, inciso I, 127 e 128 , todos, da Constituição. Este estudo foi publicado na Revista de Direito Administrativo n. 236 (RDA 236/129) e na Revista Forense ${ }^{\circ}{ }^{\circ} 375$ (RF 375/471).

40 Canotilho, J.J. Gomes. Direito Constitucional e Teoria da Constituição. $7^{\mathrm{a}}$ ed. Coimbra: Almedina, 2003, pág. 1203.

41 Ibidem, pág. 1204.

42 Ibidem, pág. 1204. 
Federal, aos Tribunais Superiores, ao Procurador-Geral da República e aos cidadãos, na forma e nos casos previstos nesta Constituição.

$\int 1^{\circ}$ - São de iniciativa privativa do Presidente da República as leis que:

(...)

$\int 2^{\circ}$ - A iniciativa popular pode ser exercida pela apresentação à Câmara dos Deputados de projeto de lei subscrito por, no mínimo, um por cento do eleitorado nacional, distribuído pelo menos por cinco Estados, com não menos de três décimos por cento dos eleitores de cada um deles.

Art.14.A soberania popular será exercida pelo sufrágio universal e pelo voto direto e secreto, com valor igual para todos, e, nos termos da lei, mediante:
(...)

III - iniciativa popular.

Art. $1^{\circ}$. A República Federativa do Brasil, formada pela união indissolúvel dos Estados e Municípios e do Distrito Federal, constitui-se em Estado Democrático de Direito, e tem como fundamento:

(..)

II - a cidadania

III - dignidade da pessoa humana

(..)

V - pluralismo político

Parágrafo único.Todo o poder emana do povo, que o exerce por meio de representantes eleitos ou diretamente, nos termos desta Constituição.

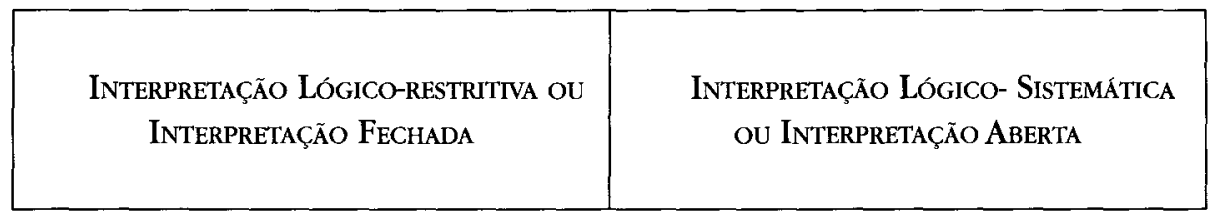

\begin{tabular}{|r|l|}
\hline \multicolumn{1}{|c|}{ Norma 1: } & \multicolumn{1}{|c|}{ Norma 2: } \\
$\begin{array}{r}\text { As reservas do } ₫ 1^{\circ} \text { se estendem a } \\
\text { todos os legitimados do caput, razão } \\
\text { pela qual, um projeto de lei, oriundo } \\
\text { da iniciativa popular, não pode tratar } \\
\text { das matérias reservadas ao Presiden- } \\
\text { te da República. }\end{array}$ & $\begin{array}{l}\text { As reservas do } \$ 1^{\circ} \text { se estendem a } \\
\text { todos os legitimados do caput, com } \\
\text { exce dos cidadãos, devidamente } \\
\text { reunidos e organizados por iniciativa } \\
\text { popular. }\end{array}$ \\
\hline
\end{tabular}


A disjunção não leva o intérprete à dúvida, mas sim, à identificação. É reconhecendo os pontos de conflito, é perquirindo cada critério interpretativo, enfim, é colocando as normas lado a lado (N1?N2?), que o intérprete pode finalmente decidir qual dessas normas deve ser aplicada.

Conforme já mencionado, a Nor ma 1 encontra sua razão de ser apenas no pressuposto lógico do texto do artigo, ou seja, para os adeptos dessa corrente, as restrições impostas pelo $\$ 1^{\circ}$ do art.61 são extensíveis a todos os legitimados - inclusive os cidadãos - apenas porque não há dispositivo que, expressamente, diga o contrário.

Todavia, a concepção de uma Constituição ou de um ordenamento jurídico não se constrói dessa maneira. A carga deontológica de uma Constituição, por exemplo, não é inspiradora de apenas um ou outro dispositivo, mas sim de todo o sistema normativo. Por detrás do termo "cidadão" ou "iniciativa popular" existe uma estrutura axiológica que transcende em muito qualquer prescrição segregada, porquanto , como dito anteriormente, cada dispositivo, isolado ou não, tem que trazer consigo o espírito do princípio que o legitima.

Nesse contexto, o magistério de Jorge Miranda é fundamental: "O Di- reito não é mero somatório de regras avulsas, produto de actos de vontade, ou mera concatenação de fórmulas verbais articuladas entre si. O Direito é ordenamento ou conjunto significativo e não conjunção resultante de vigência simultânea; é coerência ou, talvez mais rigorosamente, consistência; é unidade de sentido, é valor incorporado em regra. $E$ esse ordenamento, esse conjunto, essa unidade, esse valor projeta-se ou traduz-se em princípios, logicamente anteriores aos preceitos". ${ }^{43}$

Decompondo esta brilhante passagem de Jorge Miranda, o leitor mais avisado pode pinçar vários elementos tidos como essenciais em um ordenamento - coerência, consistência, unidade, valor e princípios - $\mathrm{e}$ assim compará-los com a Norma 2 da disjunção para perceber a total sintonia entre ambos.

A coerência e consistência dessas argumentações levam o hermeneuta ao chamado catálogo tópico dos princípios de interpretação constitucional, a saber: princípio da unidade da constituição, princípio do efeito integrador, princípio da máxima efectividade, princípio da justeza ou da conformidade funcional, e por fim, o princípio da concordância prática ou harmonização. ${ }^{44}$

43 JORGE Miranda, ob.cit.p.197-198.

44 "O catálogo dos princípios tópicos da interpretação constitucional foi desenvolvido a partir de uma postura metódica hermenêutico-concretizante. Este catálogo que os autores recortam de forma diversa tornou-se um ponto de referência obrigatório da teoria da interpretação constitucional".J.J. Gomes Canotilho, ob.cit.p.1223. 
Logo de início, é possível perceber que a unidade da constituição é sem sombra de dúvida o princípio mais defendido ao longo desse estudo. Uma Constituição deve ser estudada e interpretada em seus aspectos globais, em toda sua estrutura normativa, para acomodar os bolsões de conflito e as antinomias que porventura possam surgir ${ }^{45}$ Ligado ao princípio da unidade está o princípio do efeito integrador. Integrar para fortalecer, essa é a advertência maior do princípio. "Na resolução dos problemas jurídicoconstitucionais deve dar-se primazia aos critérios ou pontos de vista que favoreçam a integração política e social e o reforço da unidade política". ${ }^{46}$

O princípio da máxima efetividade baseia-se na assertiva de que "a uma norma constitucional deve ser atribuído o sentido que maior eficácia the dê" ${ }^{47}$, assim como o princípio da justeza (ou conformidade funcional) diz que "a interpretação da lei constitucional não pode chegar a um resultado que subverta ou perturbe o esquema organizatório-funcional constitucionalmente estabelecido (Ehmke)". ${ }^{48}$

Destes dois princípios emergem duas conclusões: a) é a interpretação defendida neste trabalho que dará a máxima efetividade ao art.61, $\$ \$ 1^{\circ}$ e $2^{\mathbf{o}}$, da Constituição, e b) ao invés de subverter a ordem estabelecida, o que tal interpretação faz é evitar futuras perturbações, já que sua linha de raciocínio é manifestamente integradora.

A iniciativa popular,é inegável, diz respeito a um direito fundamental. Mesmo que o mérito de um projeto de lei, oriundo de iniciativa popular, não verse de modo direto sobre um direito fundamental, a própria essência dessa iniciativa, por si só, já é um direito fundamental. Os direitos políticos, o direito de participar das decisões estatais, o direito de se fazer ouvir, enfim, a cidadania, é por natureza um direito fundamental.

Com ser assim, é preciso harmonizar esse direito fundamental com as demais normas reservistas da Constituição, traçando uma linha de concordância e harmonização (princípio da concordância prática ou harmonização), de maneira que as iniciativas privativas do Presidente da República não entrem em confronto com um fundamento da república (cidadania), e via de

45 Com bastante pertinência a esse princípio está o princípio da força normativa da Constituição, segundo o qual,"na solução dos problemas jurídico-constitucionais deve dar-se prevalência aos pontos de vista que, tendo em conta os pressupostos da constituição (normativa), contribuem para uma eficácia óptima da lei fundamental. Conseqüentemente, deve dar-se primazia às soluções hermenêuticas que, compreendendo a historicidade das estruturras constitucionais, possibilitam a "actualização normativa, garantindo, do mesmo pé sua eficácia e permanência". J.J Gomes Canotilho, ob cit.,pg.1226.

46 Ibidem, p. 1224.

47 Ibidem, p. 1224.

48 Ibidem, p. 1224. 
conseqüência, com um direito fundamental. ${ }^{49}$

E toda essa harmonização, como se viu, só será possível com a interpretação ora construída. Com ela, todas as perspectivas - formal e material - são observadas, preservando-se também as iniciativas privativas do Presidente da República e as regras divisórias de cada poder. E mais, não afeta a Constituição, não comete excessos, não privilegia o político em face ao jurídico (ao contrário, traz um equilíbrio entre os dois), não demonstra nenhum casuísmo, não traz incerteza, insegurança jurídica, enfim, não sacrifica nenhum dado de juridicidade ou normatividade, de modo que qualquer crítica positivista a essa interpretação resta sobejamente inócua e sem sentido.

De qualquer maneira, seja qual for o caminho, o argumento, as proposições, o fato é que todo aprofunda- mento sobre a iniciativa popular e sua relação com as iniciativas privativas do Presidente da República será no sentido de que a interpretação para esse tema tem que ser sistemática, aberta e concretista, levando-se em conta toda uma gama de princípios, fundamentos e valores constitucionais ${ }^{50}$,até porque, como define o Mestre Paulo Bonavides, tantas vezes aqui citado,"o quebrantamento do espírito da Constituição configura a maior das inconstitucionalidades." ${ }^{51}$

\section{Conclusão}

Após toda essa argumentação, destacam-se como pontos objetivos, finais e conclusivos deste estudo, os seguintes enunciados:

1. A interpretação lógico-restritiva do art.61, $\$ \Omega 1^{\circ}$ e $2^{\circ}$ da Constituição, permite concluir que as reservas do $\$ 1^{\circ}$ do art.61 (exclusões objetivas)

49 "Este princípio não deve divorciar-se de outros princípios de interpretação já referidos (princípio da unidade, princípio do efeito integrador) Reduzido ao seu núcleo essencial, o princípio da concordância prática impõe a coordenação e combinação dos bens jurídicos em conflito de forma a evitar o sacrificio (total) de uns em relação aos outros". Ibidem, p. 1225.

50 Após tudo isso, impossível não parar para pensar nessas palavras de Dworkin: " $O$ império do direito é definido pela atitude, não pelo território, o poder ou o processo (...) É uma atitude interpretativa e auto reflexiva, dirigida à política no mais amplo sentido. É uma atitude contestadora que torna todo cidadão responsável por imaginar quais são os compromisso públicos de sua sociedade com os princípios, e o que tais compromissos exigem em cada nova circunstância (...).A atitude do direito é construtiva: sua finalidade, no espírito interpretativo, é colocar o princípio acima da prática para mostrar o melhor caminho para um futuro melhor, mantendo a boa-fé com relação ao passado. É, por último, uma atitude fraterna, uma expressão de como somos unidos pela comunidade apesar de divididos por nossos projetos, interesses e convicções. Isto é, de qualquer forma, o que o Direito representa para nós: para as pessoas que queremos ser e para a comunidade que pretendemos ter". Apud Maria Elizabeth Guimalhães Teixeira Rocha, ob.cit.p.211-212.

51 Pavlo Bonavides, teoria constitucional da democracia participativa, ob.cit.p.28. 
se estendem a todos os legitimados do caput do mesmo artigo (inclusões subjetivas), razão pela qual, parte da doutrina sustenta que um projeto de lei, oriundo da iniciativa popular, não poderia tratar das matérias reservadas à iniciativa privativa do Presidente da República.

2. Esta interpretação, no entanto, é construída sob bases que fornecem um critério de certeza apenas aparente, já que pela análise isolada desses dispositivos o intérprete ficaria impossibilitado de alcançar o real significado da iniciativa popular.

3. Tal assertiva fica ainda mais digna de consideração quando se observa que essa reserva de iniciativa $\left(\$ 1^{\circ}\right.$ do art.61) baseia-se primordialmente em duas premissas: o sistema de freios e contrapesos, que pressupõe seja destinado apenas às autoridades constituídas, e o poder discricionário do Presidente da República, que pressupõe a análise da conveniência e oportunidade de um projeto de lei, antes do seu envio à Câmara dos Deputados.

4. A análise aprofundada de elementos como democracia, soberania popular, legitimidade, cidadania, etc., fornece ao hermeneuta todos os elementos doutrinários para que ele conceba uma nova perspectiva para a iniciativa popular, perspectiva esta que se desgarre das amarras positivistas, $\mathrm{e}$ dessa forma, reconheça o status constitucional diferenciado do cidadão, no que tange à iniciativa de projetos de lei, atingindo, destarte, os verdadeiros princípios, valores e fundamentos constitucionais.

5. Toda essa nova linha de orientação desemboca numa interpretação lógico-sistemática, principalmente a partir da conjugação do art. $61, \$ \$ 1^{\circ} \mathrm{e}$ $2^{\circ}$, com os arts. $1^{\circ} \mathrm{e} 14$ da Constituição, razão por que, é possível concluir que as matérias constantes do $₫ 1^{\circ}$ do art.61 da Constituição não têm efeito extensivo aos projetos de lei oriundos da iniciativa popular.

6. Não obstante os propósitos da interpretação lógico-sistemática, é preciso reconhecer também que todas as teorizações progressistas e contemporâneas possuem elementos que dão total viabilidade doutrinária para essa interpretação aberta e concretista, no tocante ao art. $61, \iint 1^{\circ} \mathrm{e} 2^{\circ}$, da Constituição.

\section{Bibliografia}

Amaral, Rafael Caiado. Peter Häberle e a hermenêutica constitucional. Alcance doutrinário. Porto Alegre: Sérgio Antônio Fabris Editor, 2004.

Benevides, Maria Victoria de Mesquita. A cidadania ativa. São Paulo: Ática, 1991.

Bonavides, Paulo. Ciência política. $10^{a}$ edição. São Paulo: Malheiros, 2005.

-, Curso de direito constitucional, $15^{\mathrm{a}}$ edição. São Paulo: Malheiros, 2004.

-, Despolitização da legitimidade. Separata da Revista "O Direito", ano $125^{\circ}$, Lisboa, 1993.

-, Teoria constitucional da democracia participativa. $2^{\mathrm{a}}$ edição. São Paulo: Malheiros, 2003. 
Canotilho, J.J. Gomes. Direito Constitucional e Teoria da Constituição. $7^{\mathrm{a}}$ edição. Coimbra: Almedina, 2003.

HÄBERLE, Peter. Hermenêutica constitucional. A sociedade aberta dos intérpretes da Constituição: contribuição para a interpretação pluralista e "procedimental" da Constituição.Tradução Gilmar Ferreira Mendes. Porto Alegre: Sérgio Antonio Fabris Editor, 1997.

Ferreira Filho, Manoel Gonçalves. Do Processo Legislativo. $4^{\mathrm{a}}$ edição.São Paulo: Saraiva, 2001, p.207.

Maximiliano, Carlos. Hermenêutica e Aplicação do Direito. $13^{a}$ edição. Rio de Janeiro: Forense, 1993.

Melo, Mônica de. Plebiscito, referendo e iniciativa popular. Mecanismos constitucionais de participação popular. Porto Alegre: Sergio Antônio Fabris Editor, 2001.
Miranda, Jorge. Manual de Direito Constitucional. Introdução a Teoria da Constituição,Tomo II. $2^{\mathrm{a}}$ edição. Coimbra Editora Ltda, 1988.

PorTo, Mario Moacyr. Revista do Curso de Direito da Universidade Federal do Rio Grande do Norte.Vol.01, n. 01. Natal: CEJ/RN, EDUfRN, 1996.

RocHA, Maria Elizabeth Guimalhães Teixeira. Limitação dos mandatos legislativos. Uma nova visão do contrato social. Porto Alegre: Sérgio Antônio Fabris Editor, 2002.

Ribeiro Junior, Ubergue.A Natureza Jurídica do Parquet Especial. Revista de Direito Administrativo n. ${ }^{\circ} 236$ (RDA 236/219) e Revista Forense n. 375 (RF 375/471).

SiLva, José Afonso da. Curso de Direito Constitucional Positivo. $19^{a}$ edição. São Paulo: Malheiros, 2000, p.130 